\title{
Pension reform in China
}

Received: 12th October, 2002

\section{Stuart H. Leckie}

is Senior Advisor to Hewitt Associates' Greater China operations, based in Hong Kong. He advises on pensions and investments in Hong Kong and mainland China, and is the author of books titled 'Pension Funds in China' and 'Investment Funds in China'. He is currently the Chairman of the International Actuarial Association's China Committee and Chairman of the Hong Kong Retirement Schemes Association.

\begin{abstract}
The paper describes the former pay-as-you-go (PAYG) pension system in China, and how this has been outdated because of demographic changes and economic reforms. The new pension system requires contributions from employees and employers, and will become at least partially funded. In addition, certain other initiatives are being developed. There will therefore be very considerable opportunities in future for fund managers.
\end{abstract}

Keywords: ageing population; previous unfunded system; World Bank; new principles; three pillar approach; pensions assets; development of capital markets; China; National Social Security Fund; pilot experiment; stock market investment; opportunities for fund managers; Technical Assistance Agreements; enterprise annuities

\section{People's Republic of China: Population}

Mainland China has a rapidly ageing population. This is attributable to two main factors: the 'one-child policy', and substantial improvements in life expectancy - leading to a rapidly deteriorating dependency ratio. The issue of China's ageing population first attracted attention in 1982, following the country's third population census. Official projections indicated that China's population was ageing faster than in any other country and the ratio of retirees to workers was deteriorating more seriously than elsewhere.

China's life expectancy has improved dramatically over the past 50 years. Today, the average life expectancy is 71 years compared to 50 years in 1949 (male and female combined). At the same time, the one-child policy has been rigorously applied in the urban sector in
China since 1979. Quite simply, this policy is arguably the most significant social experiment ever. The policy is, however, modified in its application in rural China and with the Chinese minority peoples.

The so-called 1-2-4 phenomenon, which stands for one child, two parents and four grandparents, is becoming apparent in China. In other words, one child will enter the workforce to take care of two parents and four grandparents. The Chinese government is fully aware of its ageing population, and the financial burden being created to provide and care for the elderly. It is inevitable that China's pension system will need to go through significant changes. It must also be appreciated that China's pension reforms are an integral part of the overall economic reforms and the development of China's capital markets. 


\section{Old system ('iron rice bowl')}

In the 1950s and 1960s, workers were employed for life by the state-owned enterprises (SOEs). Workers received very low but very secure wages. The old pension system was extremely generous. Males received their pension at age 60 and females at age 55 or 50 for factory workers. Pension benefits equated to about 80 per cent of final salary.

The system was operated on a pay-as-you-go (PAYG) basis. This was fine initially, but when the economic reforms put great financial pressure on the SOEs, the fact that funds had not been set aside in advance to meet pension obligations resulted in real financial strain for the SOEs, and sometimes in pensions going unpaid. China is now very concerned about social unrest resulting from unpaid pensions and the unemployed.

\section{World Bank influence}

In the 1990s, the World Bank undertook a number of studies of China's demographics and pension challenge. ${ }^{1}$

Around 1995-96 the PRC leadership in Beijing reached certain conclusions:

- China could not continue with a system that paid pensions of 80 per cent of final salary

- employers and employees must contribute towards the cost of their own pensions, rather than rely on the next generation

- the whole country should move towards a funded pension system.

The reasons for this were:

— the deteriorating demographics

- the economic reforms focusing on improved productivity and cost control in the SOEs
- the wish to develop China's capital markets.

\section{Pension principles for the future}

In July 1997 the State Council passed

Document No. 26, 'Establishment of a Unified Basic Old Age Pension Insurance System for Enterprise Staff and Workers', which stipulated contribution rates and benefits across all provinces. The reforms were broadly in line with World Bank recommendations and aimed to move the PAYG system to a system constructed under a three pillar model. This model aims to include all employees as well as the self-employed in the urban sector. The urban sector encompasses about $400 \mathrm{~m}$ people out of the total population of $1.3 \mathrm{bn}$.

\section{New system ('safety net')}

The New Unified Pension System commenced in 1999. The benefits introduced under the new system reflected the World Bank's three-pillar approach.

- Pillar I = State Basic pension of 20 per cent of average provincial wages

- Pillar II = State Individual account pension based on 11 per cent contributions

- Pillar III = Private sector Voluntary Supplementary Benefits.

The new system also included gradually increasing the retirement age to 65 years for both men and women, but this has not yet happened because of concerns over unemployment.

\section{Financing}

Under the new system, employees initially contributed 4 per cent of their salary towards financing their pensions, 
increasing by 1 per cent every two years up to 8 per cent by 2005 .

The employer contributes about 20 per cent of salary but this is subject to local variation. This percentage varies by city or municipality in China.

Contributions are payable on salaries up to three times the city average salary.

\section{Pension assets}

Pillar I and II pension assets are currently estimated to amount to approximately $¥ R M B 125 b n$ (US\$15bn), all in deposits and government bonds. These assets are managed by the local social security bureaux. The assets are, however, sadly insufficient to meet the future financing obligations of the system. The government is considering several possible ways to meet the pensions shortfall. These include the levy of special taxes, a national lottery, the issue of recognition bonds, the sale of state-owned assets and the launch of a Chinese Tracker Fund.

It is estimated that the pension assets will increase at an annual rate of at least 30 per cent for the next several years. According to a World Bank forecast, by the year 2030 the accumulated pension assets in China could reach US $\$ 1.8$ trn.

\section{Development of China's capital markets}

Since the Asian Financial Crisis of 1997-98, economic development in China has been focused on stimulating domestic demand. The country has a high savings rate at 40 per cent of GDP, with bank deposits reaching US\$900bn in 2001. Mobilising domestic savings is central to future sustainable growth. To this end, the capital markets, especially the stock markets, are the key.

Over the past decade, the role of the stock markets has been narrowly focused on fundraising, with little regard for the efficiency of capital allocation. In future, the government wishes to emphasise efficiency, competition and accountability in the stock markets.

The intention will be gradually to permit a portion of the pension assets to be diversified in equities or domestic investment funds.

\section{National Social Security Fund (NSSF)}

In September 2000, a National Social Security Fund was established under the administration of the State Council. This was an effective admission that certain provinces are simply unable to meet the transition costs of the old pension system to the new system.

In the event that some provinces have insufficient funds for Pillars I and II, the NSSF is a 'fund of last resort'. The moneys coming into this fund from the sell-off of state-owned shares is equal to 10 per cent of all initial public offerings (IPOs) and rights issues. Recently, however, this policy has been suspended for domestic issues (but not for international fundraising), because of weakness in the stock markets.

The National Council for the Social Security Fund is to act as Trustees. External fund managers will be allocated part of the investments to manage. The rules for distribution of subsidies to the worst-off provinces by way of loan or grant are not yet determined.

\section{Liaoning experiment}

To address the challenges in implementing Document 26, the State Council issued Document 42, an 'Experimental Project for Improving the Social Security System', to be carried out in Liaoning Province.

As a result, a three-year pilot 
experiment has been introduced in Liaoning in 2001 as a modification of Document 26. The major reason for choosing Liaoning is that this province has especially serious economic and funding problems. Liaoning was the most industrialised province in China, and now is burdened with large numbers of both unemployed workers and retirees.

The major features of the Liaoning Experiment are:

- pension benefits under Pillar I will increase to 30 per cent of provincial average wages after 30 years of employment

- all employer contributions go to Pillar I

- Pillar II will be funded entirely by employees with 8 per cent contributions and will contain real assets (not notional accounts.)

The result of this pilot project will determine the future development of China's social security system.

\section{Stock investment}

To allow pension funds to invest in equities is a controversial issue in China, although the controversy is largely a matter of timing. One study sponsored by the Ministry of Labour and Social Security (MLSS) recommended that China's pension funds be allowed to invest in the stock market, in order to produce a better return for the deficit-stricken pension funds and help develop the growth of institutional investment.

The stock markets should be keen to welcome pension investment. The report suggested that the operation of China's capital markets is maturing and that there are sufficient financial vehicles for pension investment.

\section{Opportunities for fund managers}

In China, the provincial governments manage Pillar I and Pillar II assets and sometimes the Pillar III Supplementary Pension Plans. Participants and employers have no say in the investment of their pension funds. The funds are simply invested in low-yield bank deposits and treasury bonds. Only where a Pillar III supplementary plan is arranged through a with-profit or unitised pension product, will there be partial indirect investment in equities.

In order to improve investment returns, investment options will have to be broadened and qualified fund management companies be invited to manage pension fund portfolios. On an international basis comparative performance data clearly show that privately managed funds outperform publicly managed ones. For most countries, both developed and developing, the equities market usually outperforms government bonds and savings deposits over the longer term. In the light of China's WTO accession, a number of international fund managers have established Technical Assistance Agreements (TAAs) with domestic fund management and securities companies. ${ }^{2}$

Under a TAA, the international fund manager commits to giving training to the domestic manager on all aspects of a progressive fund management operation. During this time the parties will get to know each other, and may decide to convert the courtship into a marriage through a joint venture fund management arrangement.

By October 2002, there were 19 approved Chinese fund management companies managing over 60 closed-end funds and six open-ended funds with total assets of US $\$ 10 \mathrm{bn}$. However, the value of these investment funds only accounts for about 6 per cent of the stock market by free float stock market 
capitalisation. Regulations permitting investment of a portion of the pension fund assets into the stock markets may be unveiled in 2003 .

\section{'Enterprise Annuity' system}

Under Document 42, the government stated that it wishes to encourage employers to establish an 'Enterprise Annuity' scheme for their employees. 'Enterprise Annuity' is the term used by the MLSS for a supplementary pension plan. The MLSS seems determined to take the initiative in developing this area rather than leave it to the insurance companies or their regulator, the Chinese Insurance Regulatory Commission (CIRC).

In order to introduce an Enterprise Annuity scheme, the enterprise should be profitable and should be up-to-date with its Pillar I and Pillar II contributions. Provided that the scheme is implemented in a manner approved by the MLSS, the employer will receive tax relief on contributions of up to 4 per cent of payroll. The MLSS wishes the Enterprise Annuity system to develop in an unbundled fashion where administration and fund management are handled separately — very different from the type of supplementary pension product offered by insurance companies and approved by the CIRC.

\section{Conclusion}

The changes to China's pension system are very major and very serious.

Provided high economic growth continues for many years, there is a chance that the new system will succeed. On the other hand, there are great risks and real difficulties. It must be emphasised that the pension system forms an integral part of the overall economic reforms and of China's capital market development. There is no simple solution and in many ways China is in a race against time to make the pension reforms work.

\section{References}

1 World Bank studies include: 'China Pension System Reform' (1996); 'How Can China Provide Income Security for its Rapidly Ageing Population?' (1996) 'Pension Reform in China: Old Age Security' (1997).

2 Some of the international firms which have TAAs with Chinese firms are: ABN Amro, Allianz Dresdner, Bank of Montreal, BNP Paribas, Commerzbank, Deutsche, Fortis, Franklin Templeton, ING, Invesco, JP Morgan, Prudential (UK), Prumerica Financial (US), Schroders, Société Générale, UBS. 